\title{
Reviewer Acknowledgements for Global Journal of Health Science, Vol. 11, No. 12
}

Global Journal of Health Science wishes to acknowledge the following individuals for their assistance with peer review of manuscripts for this issue. Their help and contributions in maintaining the quality of the journal are greatly appreciated.

Global Journal of Health Science is recruiting reviewers for the journal. If you are interested in becoming a reviewer, we welcome you to join us. Please find the application form and details at http://recruitment.ccsenet.org and e-mail the completed application form to gjhs@ccsenet.org.

\section{Reviewers for Volume 11, Number 12}

Abin Varghese, Ministry of Health and Family Welfare, India

Abiodun Adeniran, University of Ilorin, Nigeria

Ahmed Hassan Ghada, Menoufia University, Egypt

Althea (Alfie) Gamble Blakey, University of Otago, New Zealand

António Calha, Polytechnic Institute of Portalegre, Portugal

Arpad Kovacs, University of Kaposvar, University of Pecs, Hungary

David Otieno Odongo, Masinde Muliro University of Science and Technology, Kenya

David Richard Walwyn, University of Pretoria, South Africa

Domitila Augusta Huber, Federal University of Santa Catarina, Brazil

Emad Adel Shdaifat, Imam Abdulrahman Bin Faisal University, Saudi Arabia

Evangelia Mavrikaki, National \& Kapodistrian University of Athens, Greece

Evanthia Sakellari, Technological Educational Institute of Athens, Greece

Farahnaz Amini, UCSI University, Malaysia

Francisco Rodenas Rigla, University of Valencia, Spain

Gabriel Gulis, University of Southern Denmark, Denmark

Gavric Zivana, University Banja Luka, Bosnia and Herzegovina

Georgann Valerie Weissman, Capella University, United States of America

Loray Daws, British Columbia Masterson Institute, Canada

Meng Zhao, Texas A\&M University at Corpus Christi, United States of America

Misheck Dube, North West University, South Africa

Pi-Ming Yeh, Missouri Western State University, United States of America

Roger Ho, National University of Singapore, Singapore

Samir Othman, Hawler Medical University, Iraq

Shelley Wall, University of KwaZulu-Natal, South Africa

Tan Ching Siang, Universiti Sciences Malaysia, Malaysia

Thanusin Saleeon, Ministry of Public Health, Thailand 